\title{
Saltbush Biomass for Energy
}

\author{
Manuel Paneque* \\ Department of Environmental Sciences and Natural Resources, University of Chile, Chile
}

Submission: March 21, 2018; Published: April 06, 2018

"Corresponding author: Manuel Paneque, Department of Environmental Sciences and Natural Resources, Faculty of Agricultural Sciences, University of Chile, Santa Rosa 11,315, La Pintana, 8820808 Santiago, Chile, Tel: +56-2-2978-5863; Email: mpaneque@uchile.cl

\section{Opinion}

The bioenergy development has a strategic nature and responds to the need to diversify the energy matrix. The challenge is to contribute to the search for species that adapt to lands whose current use is not related to food production and have energy potential. It is necessary that the energy production in Chile be carried out mainly based on the expansion of agroforestry border and valorization of native and non-native species.

In Latin America, 23 million $\mathrm{m}^{3}$ year-1 of forest waste are wasted, enough to supply 20 million people year $^{-1}$, this wood could replace 6 million $\mathrm{m}^{3}$ year-1 of oil. In northern Chile, the woody resource is overexploited at the rural level, with depletion risk and increasing intensity of desertification [1].

The Edaphic, physiographic and climatological conditions of northern Chile have registered gradual changes during the last years. These variations in the environment are generally unfavorable to agroforestry production because they involve greater risks of frost and drought, high degrees of erosion and low soil fertility [1]. In the plant kingdom, in the Chenopodiacea family, there are species that adapt to the adverse climate conditions and soil, among the best known, we can mention the genus Atriplex (saltbush), the genus Chenopodium, quinoa (Ch quinoa) and paico (Ch. ambrosioides). Most of these species colonize arid, saline and organic matter poor soils, considered marginal for other crops or forest species [2,3].

There are many saltbush species in the genus Atriplex. It is composed of shrub, herbaceous, perennial and annual plants. Saltbush species have plasticity in terms of adaptation; most of them colonize semi-arid and arid zones of the planet. There are several native and introduced saltbush species; most of these have low percentage of regeneration and natural repopulation due to the hardness and dormancy of the seed $[1,4]$.

Saltbushes are well adapted to grow in salty or alkaline sites where the soils are silty or gravelly and thus retain little water [3]. Often they are the only plants that can tolerate these conditions, so they can form large stands. All these plants have greyish-green leaves with hairs that secret excess salt onto the leaf surface, to maintain the plant's internal salt balance. The common desert species include shadscale, four-wing saltbush, desert holly and desert saltbush [5]. They often exhibit a special type of photosynthesis called $\mathrm{C} 4$ photosynthesis, which allows them to synthesize sugars - albeit sometimes at a low rate - in the hottest conditions, when other plants close their photosynthesis [6].

The taxonomic identification of saltbush species is very complex because they exhibit variability between and within themselves [3]. This diversity is attributed to the genetic plasticity and natural hybridization occurring within the genus, determining which species are favored to colonize new areas. This particularity makes taxonomic identification of the species difficult $[5,6]$.

In Chile saltbush species are mainly concentrated in the arid zones of regions XV, I, II, III and IV, mostly in saline and alkaline soils, and they constitute a palliative as fodder in times of drought [3,7]. The genus Atriplex, presents wide possibilities of production, the use of secondary or primary byproducts of its processing, can be transformed into pellets or briquettes [4]. The following saltbush species stand out as firewood producers, in decreasing order: A. nummularia, A. halimus, A. undulata, A. atacamensisy, A. canescens, whose average yield exceeds $10 \mathrm{~kg}$ of dry wood plant-1 $[3,5,6]$. The species introduced to Chile produce higher firewood yields than the native ones, and the yields obtained are high compared to those of the local shrub vegetation.

The saltbush species is studied for bioenergetic purposes in the Agricultural Center of High Altitude Desert near to Zaldivar mine (Antofagasta Minerals), as part of its commitment to innovation in geographical areas under extreme agro-climatic conditions. The challenge is to grow and thrive at an oxygendeprived altitude of 3.300 meters above sea level, in the second driest region on Earth. This project of innovation in geographical 
areas under extreme agro-climatic conditions, integrates mining soils to agricultural production, and takes advantage of the technical advisory team experience from the University of Chile, Chilean National Forestry Corporation (CONAF) and Agroenergía SA, a Chilean green energy company.

The plantation takes place in a sandy loam soil with severe salinity problems and irrigation water with high boron concentrations, which range between 7-9 $\mathrm{mg} \mathrm{L}^{-1}$ and which comes from a treatment and recovery system through Toha system [8].

Studies with the ecotypes A. nummularia, A. halimus and A. canescens, have shown resistance to temperatures of $-16{ }^{\circ} \mathrm{C}$, wide thermal oscillations, yields between $6-12 \mathrm{~kg}$ of fresh matter plant1, and generating up to 11.7 times more energy than what is consumed, which makes it an exceptional species for the production of biofuels, also it can capture up to five tons of carbon dioxide per year. The analysis of the biomass indicates that this species has a calorific value between 4.200 and $4.500 \mathrm{kcal} \mathrm{kg-1}$ equivalent to $64 \%$ of the energy of mineral coal, $41 \%$ of the national crude oil and $48 \%$ of the gas energy natural.

Saltbush can be considered an agro-energy resource, which contributes to soil protection, improves the incorporation of organic matter, prevents erosion and improves the capacity of soil moisture retention. All this allows the species to be incorporated in an eco-friendly way, so that the new energy industry coexists with the mining and agricultural industries.

Some of the main reasons for the use of pellets as fuel are:

a. It reduces the dependence on fuels such as coal, firewood, oil and its derivatives of fossil origin.

b. It is a source of renewable energy.

c. It is produced from the waste of the forest industry, so that its production does not exert pressure on the environment and its natural resources.

d. It does not present large variations in terms of prices in the international market, unlike what happens with other fuels of traditional use.

e. It produces a low quantity of both solid and gaseous residues at the moment of its combustion. f. It constitutes an alternative in the generation of energy and heating in cities where there are restrictions in relation to the emissions of gases and this has resulted in the prohibition of using wood stoves or fireplaces.

g. Processing the material usually involves grinding, drying and pressing it to different shapes and sizes. Additives can be used to improve the adhesion of the material; even though the natural lignin in wood is normally sufficient for this purpose.

Saltbush biomass production in extreme conditions for bioenergy can contribute to the adaptation of arid ecosystems to global changes, valorize species with potential for carbon capture and contribute to reducing pressures that drive the biodiversity loss in the world.

\section{References}

1. Paneque M, Román C, Vásquez-Paniza R, Arriaza JM, Morales D, et al. (2011) Bioenergía en Chile. In: Paneque M (Ed.), Universidad de Chile, Santiago, Chile, p. 124.

2. Osmond C, Bjrkman O, Anderson D (1980) Physiological processes in plan ecology. Towards a synthesis with atriplex. Springer-Verlag. Berlin Heilbelbeg, New York, USA, p. 467.

3. Roza M (1989) El género Atriplex (Chenopodiaceae) en Chile. Gayana, Bot, 46(1-2): 3-82.

4. Román C, Vásquez K, Martínez G, Lillo G, Fuster R, et al. (2012) Cultivos energéticos una apuesta de futuro. In: Paneque M (Ed.), ( $2^{\text {nd }}$ edn), Universidad de Chile, Santiago, Chile, p. 224.

5. Lailhacar S, Riveray H, Caldentey J (1995) Rendimiento de leña y recuperación al corte en diferentes especies y procedencias arbustivas del género Atriplex. Revista de Ciencias Forestales 10: 85-97

6. Le Houérou H (1992) The role of saltbushes (Atriplex spp.) in arid land rehabilition in the Mediterranean basin: a review. Agroferstry systems 18(2): 107-148.

7. Zulantay M, Paneque M, Román-Figueroa C, Uribe JM, Celis C, et al. (2013) Biomasa en el Desierto de Chile. Paneque M (Ed.), Universidad de Chile, Santiago, Chile, p. 128.

8. Soto MA, Toha (1998) Ecological Wastewater Treatment, Proceedings Advanced Wastewater Treatment. Recycling and Reuse, AWT 98, Milano.

Your next submission with Juniper Publishers will reach you the below assets

- Quality Editorial service

- Swift Peer Review

- Reprints availability

- E-prints Service

- Manuscript Podcast for convenient understanding

- Global attainment for your research

- Manuscript accessibility in different formats

( Pdf, E-pub, Full Text, Audio)

- Unceasing customer service

Track the below URL for one-step submission https://juniperpublishers.com/online-submission.php 